The contrary opinion of the court of appeals was also based on testator intent. In holding that the trusteeship was not vacated by the first consolidation, ${ }^{23}$ the court said: "[I]nasmuch as the testator was presumed to know that consolidation might occur, he necessarily contemplated that it would occur and that, when consolidation did occur, he intended what the laws says [sic], name$\mathrm{ly}$, that the functions of the merging corporations would pass to the new corporation." In ruling on the consolidation with First National, the court extended this presumption of knowledge and intent to include the McFadden Act, enacted after the testator's death. This extension exposes the presumption as mere judicial gesturing, which might well have been dispensed with in favor of a clear statement of the policy considerations underlying this sound decision.

\title{
STANDING TO ATTACK SPENDTHRIFT TRUST CREATED BY BENEFICIARY
}

"Even in jurisdictions in which spendthrift trusts are permitted, the settlor cannot create a spendthrift trust for his own benefit." ' This general precept certainly means that the settlor's creditors ${ }^{2}$ and probably his voluntary alienees ${ }^{3}$ can reach the settlor's interest in such a trust, but it has not been entirely clear whether the settlor himself or another beneficiary ${ }^{4}$ could attack the trust on the theory that it is contrary to public policy. While Professor Bogert does state that such a spendthrift trust "should be subject to attack by the creditors only," 5 most of the other authorities do not specifically mention the settlor or beneficiary in this connection. Moreover, ambiguous statutes have beclouded the issue, ${ }^{6}$ and the question has rarely arisen before the courts. ${ }^{7}$

${ }^{23}$ The court maintained that the appointed trustee lived on in the consolidated corporation, and only died with respect to "formal legal existence." While manipulation of the various aspects of the concept of corporate entity have been a traditional part of the law of this subject, the above exposition would seem to be unavailable in Illinois, where the cases, including the Zinser case, have invariably held the constitutent corporate entities to be dissolved on consolidation. See Scheidel Coil Co. v. Rose, 242 Ill. 484, 90 N.E. 22I (I909); Chicago Title \& Trust Co. v. Doyle, 259 Ill. 489, 102 N.E. $79 \circ$ (I9I3). (r939).

× Scott, Trusts $\S x_{5} 6$ (I939). Such a trust is sometimes said to be "invalid." IIg A.L.R. 35

${ }^{2}$ Mackason's Appeal, 42 Pa. 33० (I862); Rest., Trusts $\S$ I56(e) (I935); I Scott, Trusts $\S$ I56 (1939); I Bogert, Trusts and Trustees $\$ 224$ (1935).

3 Byrnes v. Comm'r, rro F. 2 d 294 (C.C.A. 3 d, I940); City Bank Farmers Trust Co. v. Kennard, I N.Y.S. 2d 369 (1937); Rest., Trusts $\$ 156$ (e) (I935); I Bogert, Trusts and Trustees $\$ 224$, at 734 (I935). Contra: Hackley v. Littell, I5० Mich. I06, IX3 N.W. 787 (I907); see II9 A.L.R. 37 (I935); I38 A.L.R. I323 (I942).

4 Or perhaps the settlor himself in his capacity as a beneficiary.

5 I Bogert, Trusts and Trustees $\S 224$, at 734 (1935).

${ }^{6}$ See text at note $I 7$ infra.

7 Perhaps this is because few settlors ever thought they could succeed in getting the courts to allow them to attack the trust for an invalidity which the settlors themselves created. 
In Liberty Nat. Bank v. Hicks ${ }^{8}$ this problem was put squarely before the Court of Appeals of the District of Columbia. John Hicks, prior to his divorce, executed a trust agreement whereby he was to get a life income and, on his death, one-half the assets were to be distributed to his three children and onehalf to those appointed in his will, or, a will lacking, to his heirs at law. In the instrument, which was declared irrevocable, Hicks attempted to free his life interest from liability for his debts ${ }^{9}$ and to give his trustee discretionary power to use the capital of the trust for his benefit in an emergency. ${ }^{\mathrm{x}}$ Hicks later remarried and had a child by his second wife. Thereafter, he executed an instrument revoking the trust, notified the trustee that he had given his present wife and child the one-half interest he had reserved the right to dispose of by will, and requested the trustee to deliver up the entire corpus. On the trustee's refusal, Hicks brought suit to have the trust declared void as against public policy.

The court pointed out that the settlor was trying to use for his own benefit "certain rules of public policy designed to prevent a debtor from tying up his property so that it is immune from attachment by a creditor," ${ }^{\mathrm{II}}$ and that these rules did not operate where the settlor was trying to invalidate the trust. The court held that even if the spendthrift provision were invalid, it was "severable" and did "not destroy the whole agreement." In addition, the entire trust was held to be irrevocable and the attempted gift to Hicks' present wife and child ineffective.

In refusing to let the settlor benefit by the public policy rule which voids spendthrift trusts created for the settlor, the court properly went behind the rule to find the reason for its existence and considered the fact situation in the light of that reason. The court may also have noted that the settlor himself caused the illegality and therefore, having unclean hands, could not expect relief from a court of equity. The case most similar to the Hicks decision is Citizens E. Southern Nat. Bank v. Howell, ${ }^{\mathrm{x}}$ where the majority held the trust valid, claiming that the rule of public policy applied only to creditors. A vigorous dissent,

${ }^{8} 73$ F. 2d 63 I (App. D.C., I948).

- Creditors could have attached the settlor's life income and the one-half of the capital over which the settlor had a power of appointment, the spendthrift clause to the contrary notwithstanding. I Bogert, Trusts and Trustees $\$ 224$, at 732-33 (1935).

to Despite this clause, the three children by the settlor's first wife acquired vested interests. Jones v. Old Colony Trust Co., 25I Mass. 309, I46 N.E. 716 (1925); Rest., Trusts § 37 (I935); 6 Bogert, Trusts and Trustees $\$$ IX8I (1935); r Scott, Trusts $\$ 37$ (1939).

${ }^{x 1}{ }_{73}$ F. $2 d$ 63x, 634 (App. D.C., I948).

x2 Ibid. The rule of severability applies when the illegal provision can be separated from the other provisions without defeating the essential purpose of the settlor in creating the trust. Rest., Trusts $\S 65$ (1935); I Bogert, Trusts and Trustees $\S 2$ II (1935); I Scott, Trusts $\S 65$. I (1939). And if the rule applies where creditors are involved, "how much stronger are the reasons for its application where no creditors are concerned but only the settlor of the trust claiming the right to change his mind to the hurt of beneficiaries. . . " Liberty Nat. Bank v. Hicks, I73 F. 2d 63I, 634 (App. D.C., I948).

33 I 86 Ga. 47, I96 S.E. 74I (I938). 
however, pointed to a provision in the Georgia code ${ }^{\mathrm{I}} 4$ which prohibited settlors from being beneficiaries; and, although the majority had brushed the code aside, ${ }^{15}$ the court was obliged to say in the same term ${ }^{16}$ that the Howell case had turned on the fact that the gift over had been "upon the further trust" to the remaindermen instead of an outright gift to them.

Some states ${ }^{17}$ have attempted to copy an old English statute ${ }^{18}$ which stated that all trusts created by the settlor for himself shall be "void and of none effect," thereby creating the impression that the statute voided all such trusts $a b$ initio rather than merely the spendthrift provisions of those trusts. ${ }^{19}$ Fortunately the courts in these jurisdictions have interpreted the statutes as applying only where the intended trust is for the sole benefit of the settlor ${ }^{20}$ and as making such trusts void only as against creditors. ${ }^{25}$ After the Kansas Supreme Court said it would apply a literal interpretation ${ }^{22}$ to a statute declaring such trusts to be "utterly void and of no effect," ${ }^{23}$ at least one commentator ${ }^{24}$ became fearful that this decision might "void many of the existing trusts in Kansas." Recent Kansas legislation-undoubtedly a result of the court's interpretation-amended the law to render spendthrift trusts for the benefit of the settlor "valid except as to all creditors, past, present or future." ${ }^{\prime 25}$

In holding the half interest, over which Hicks had a power of appointment, to be irrevocable, the court appears to be on sound ground since Hicks reserved only the right of testamentary disposition and since he agreed in the instrument that the trust was not to be "altered, amended, or revoked." However, the court could have decreed a partial termination of the trust so far as Hicks' interest was concerned. ${ }^{26}$ There does not seem to be any valid reason why his

x4 Ga. Code (I937) §§ ro8-Ir4.

${ }^{x}$ With the statement that "[w]e have no Code section or statute that requires us to reach such a conclusion." Citizens \& Southern Nat. Bank v. Howell, 186 Ga. 47, 55, I96 S.E. 74x, 745 (1938).

${ }^{16}$ Clark v. Baker, 186 Ga. 65, 70, 196 S.E. 750, 754 (1938).

17 Ohio Code Ann. (Throckmorton, I948) § 8617; Kan. Gen. Stat. (Corrick, I935) §§ 33-Ior. Many states accomplish the same result by listing the classes of persons who can be beneficiaries, e.g., Ga. Code (r937) $\$ \$$ ro8-ri4.

${ }^{8}{ }_{3}$ Hen. VII, c. 4 ( 1487 ).

"Some decisions involving creditors' rights under such trusts are also guilty of this ambiguity. See Kuhn v. Jacksman, 32 Ohio App. I64, I66 N.E. 247 (I929); Sargent v. Burdett, 99 Ga. IIr, 22 S.E. 667 (I895).

${ }^{20}$ Rest., Trusts $\$$ II4 (I935).

${ }^{2 x}$ See Webb v. Roff, 9 Ohio St. 430 (I859).

$2=$ Herd v. Chambers, $5^{8} 8$ Kan. 6r4, I49 P. 2d 583 (I944).

${ }^{23}$ Kan. Gen. Stat. (Corrick, I935) \$\$ 33-Ior.

24 Trusts Created for the Benefit of the Settlor, I6 J. Bar A. Kan. $43^{\circ}$ (1948).

${ }^{25}$ Kan. L. (r949) c. 274.

${ }^{26}$ Wayman v. Follansbee, 253 Ill. 602, 98 N.E. 2I (rgI2); Rest., Trusts $\S 240$ (2) (I935); Griswold, Spendthrift Trusts $\$ 497$ (1936). Hicks' interest here consists of one-half the trust 
present changed intent with respect to his own interest should not be respected, but it can be argued that the issue of termination-as distinct from revocation -was not before the court.

However, in following Hackley ข. Littell ${ }^{27}$ to rule out the attempted gift of one-half the trust res to would-be transferees (Hicks' present wife and child), the court appears to be in the minority. ${ }^{28}$ Public policy is opposed not only to devices by which one frees his own property from liability for his debts but also to those by which he restricts his power of alienation over his own property.29 Thus Hicks should have been able either to transfer his one-half interest to his wife and child or to effect a termination of his interest. In disallowing the one and not considering the other, the court-possibly from a desire to punishappears to have treated Hicks more harshly than a strict majority view of the law warranted.

The case leaves unanswered the question whether the settlor acting in his capacity as beneficiary or a beneficiary other than the settlor ${ }^{30}$ can attack such a trust. It might be argued that a beneficiary, who is not a mere stranger to the trust like the settlor, should be able to point out any illegality to the court and have the trust declared void. Nevertheless, we might well expect the court-if such a case arises- to follow the Hicks line of reasoning and hold that the rationale for the public policy rule regarding spendthrift trusts created for the settlor applies neither to the settlor nor to the beneficiary.

While there are some who question the soundness of the rule invalidating spendtbrift trusts created by the settlor for himself, $3 x$ there ought to be little disagreement that such a rule should apply only to the persons for whom it was designed, creditors and transferees. All that the rule should mean is that the spendthrift provisions of such trusts are void-not the trusts themselves. $L i b$ erty Nat. Bank v. Hicks, despite its disagreement with the majority view on the rights of transferees and its failure to consider the settlor's right to terminate his interest, has made this more clear by providing a substantial precedent to the effect that a settlor-and inferentially a beneficiary-cannot use for his own benefit the rule regarding spendthrift trusts created by the settlor for himself.

property. Rest., Trusts $\S 127$ (Supp., I948); see Burton v. Boren, 308 Ill. 440, ₹39 N.E. 868 (1923).

${ }^{27}$ I50 Mich. I06, II3 N.W. 787 (I907).

${ }^{88}$ Authorities cited note 3 supra.

99 "Public policy does not countenance devices by which one frees his own property from liability for his debts or restricts his power of alienation of it." 54 Am. Jur. I34 (I945).

$3^{\circ}$ Perhaps to gain a larger share by intestacy laws or to get the trust capital immediately.

${ }^{31}$ Costigan, Those Protective Trusts Which Are Miscalled 'Spendthrift Trusts' Re-examined, 22 Calif. L. Rev. 47 I (I934); Griswold, Spendthrift Trusts § 557, at 476 (I936). 